\title{
TAXONOMIC POSITION AND IDENTITY OF STENOCEPHALUM MONTICOLA (VERNONIEAE, ASTERACEAE)
}

\author{
MASSIMILIANO DEMATTEIS \& MARIA BETIANA ANGULO \\ Instituto de Botánica del Nordeste (UNNE-CONICET), Casilla de Correo 209, \\ 3400 Corrientes, Argentina; e-mail: mdematteis@agr.unne.edu.ar
}

\begin{abstract}
SUMMARY
The genus Stenocephalum (Vernonieae, Asteraceae) includes six South American species that have cylindrical heads, 4-11 florets by capitula, cymose inflorescences and type 'C' pollen. Until now, Stenocephalum monticola has been considered as a synonym of S. apiculatum. However, the analysis of the type material and additional specimens indicate that it is a quite different species, which differs in leaf size, pubescence and capitula arrangement. Stenocephalum monticola has leaves of 9-20 mm long, leaf blades villous at the base and capitula agglomerate at the stems tips, while S. apiculatum presents leaves of 30-60 mm long, leaf blades basally glabrous and heads mostly solitary, arranged in a pseudo-spiciform inflorescence. Consequently, in this paper $S$. monticola is resurrected from the synonymy of S. apiculatum, re-described and illustrated.
\end{abstract}

Key words: Vernonia, Compositae, South America, Brazil, taxonomy.

\section{INTRODUCTION}

The genus Stenocephalum Sch.Bip. comprises six species widely distributed in South America, but often concentrated in southern Brazil. It was resurrected by Robinson (1987) from synonymy with Vernonia as part of a series of studies on the Lepidaploa group. After Schultz's (1863) description it was subsequently described as a section of Vernonia (Baker 1873) and then a subsection of Vernonia sect. Vernonia (Jones 1979), and recognized as such until Robinson's work. The species are perennial herbs or shrubs with xylopodia, 4-11 florets per capitula and cylindrical heads grouped in cymose inflorescences. One of the most distinctive characteristics of the genus is the pollen type, which has been designated as type 'C' by Keeley \& Jones (1979). The pollen type ' $\mathrm{C}$ ' is tricolporate, echinolophate, with lacunae disposed in a regular pattern, having a lacuna at each pole (Dematteis 2007).

Stenocephalum monticola (Mart. ex DC.) Sch.Bip. has been traditionally considered as a synonym of the widespread S. apiculatum (Mart. ex DC.) Sch.Bip. However, a detailed examination of the type material showed that it is certainly different from the latter, especially in leaf size, pubescence and capitula arrangement. Stenocephalum monticola has leaves of 9-20 mm long, the leaf blades are villous at the base and the capitula are agglomerate at the stem tips. On the other hand, S. apiculatum has leaves 
of 30-60 mm long, leaf blades basally glabrous and the heads are mostly solitary, arranged alternately along the stems in a pseudo-spiciform inflorescence.

In this paper $S$. monticola is differentiated from $S$. apiculatum and described as a different species. A key is provided to distinguish the six species of Stenocephalum.

\section{MATERIALS AND METHODS}

This study was based on morphological analysis of specimens deposited at C, CEPEC, ESA, G-DC, HUEFS, M, MBM, P, RB, SPF and UEC (Holmgren et al. 1990).

The pollen grains were acetolysed according to the procedure suggested by Erdtman (1966). For light microscopy (LM) the pollen samples were mounted in glycerinejelly on glass slides and then examined with a Zeiss Axioplan microscope. Permanent slides were deposited at the Palynological Laboratory of the Universidad Nacional del Nordeste (PAL-CTES). For scanning electron microscopy (SEM), acetolysed pollen grains were first washed in $96 \%$ alcohol and absolute alcohol, next sputter-coated with gold-palladium and then observed in a JEOL 5800 LV scanning electron microscope. The terminology applied for pollen grain description in general follows Keeley \& Jones (1979) and Punt et al. (1994).

\section{RESULTS}

\section{STENOCEPHALUM Sch.Bip.}

Stenocephalum Sch.Bip. (1863) 385. - Type: Vernonia apiculata Mart. ex DC. Vernonia sect. Stenocephalum (Sch. Bip.) Baker (1873) 25.

Vernonia sect. Vernonia subsect. Stenocephalum (Sch.Bip.) S. B.Jones (1979) 437.

\section{KEY TO THE SPECIES OF STENOCEPHALUM}

1a. Capitula commonly agglomerate at the stem apex $\ldots \ldots \ldots \ldots \ldots$

b. Capitula solitary to agglomerate, axillary, regularly disposed along the stem or its

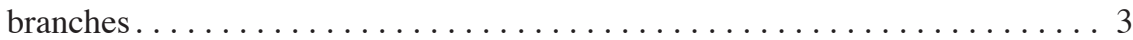

2a. Cauline leaves obovate to oblanceolate. Florets 9-11 . . . . . . . . . . . . . . . S. tragiaefolium (Mart. ex DC.) Sch.Bip.

b. Cauline leaves linear. Florets 5 or $6 \ldots \ldots \ldots \ldots \ldots \ldots$ S. monticola

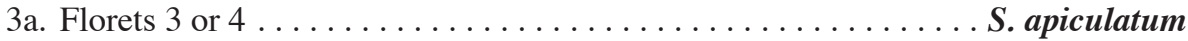

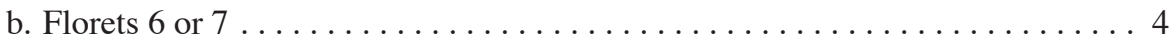

4a. Heads solitary, axillary, laxly disposed along the stem. Leaves narrowed at base 5

b. Heads often agglomerate, densely arranged in the stem and short branchlets. Leaves

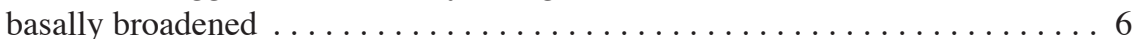

5a. Leaf blades narrowly linear............. S. hystrix (Chodat) H. Rob.

b. Leaf blades ovate. . . . . . . . . . . . . S. jucundum (Gleason) H. Rob.

6a. Phyllaries lanceolate, apiculate and curved at apex. .............

S. megapotamicum (Spreng.) Sch.Bip.

b. Phyllaries oblong-lanceolate, subobtuse and appressed at apex . . . . . . . . . 
Stenocephalum monticola (Mart. ex DC.) Sch.Bip. - Fig. 1, 2

Stenocephalum monticola (Mart. ex DC.) Sch.Bip. (1863) 386.

Vernonia monticola Mart. ex DC. (1836) 18; Baker (1873) 25. - Type: C. Martius s.n. (holo M; iso

G-DC, P), Brazil, Minas Gerais, Monte Itambe, ao Matto Dentro.

Vernonia nettoana Glaz. (1905) 372, nom. nud.

Erect shrub, 20-50 cm height. Stems 2-5, woody, terete, lanate to tomentose, densely leafy to the inflorescence, 1.5-2 mm diam. at the base. Internodes 1-3(-5) mm long. Leaves coriaceous, erect, dense, sessile. Leaf blades narrowly linear to oblong-linear, $0.9-1.7(-2) \mathrm{cm}$ long, $0.15-0.2 \mathrm{~cm}$ wide, 1-nervate, entire, revolute at the margin, apically acute to acuminate, scabrous to pilose above, laxly to densely lanate beneath. Capitula 3-6, sessile, disposed in a dense single cluster at the stem top. Leafy bracts of the inflorescence linear, as long as the heads. Involucre cylindrical, 6- or 7-seriate, $8-9.2 \mathrm{~mm}$ high, 2.3-3 mm wide. Phyllaries coriaceous, narrowly oblong to lanceolate, sparsely pilose, the inner ones aristate at the apex, 6-7.5 $\mathrm{mm}$ long, middle phyllaries shortly aristate, 5-6.4 mm long, outer phyllaries acuminate, 3-4.3 $\mathrm{mm}$ long, subglabrous. Florets 5 or 6, violet. Corollas glabrous, 9-9.5 mm long, lobes lanceolate, $3.5-4.5 \mathrm{~mm}$ long. Anthers basally calcarate, 3-3.3 mm long. Style pilose, $10-11 \mathrm{~mm}$ long, branches linear, 2-2.2 mm long. Cypselas densely sericeous, 2.5-3 mm long. Pappus greyish, inner bristles 5-6 mm long, outer scales 1-1.2 mm long. Pollen grains subspherical, echinolophate, 35-38 $\mu \mathrm{m}$ diam., tricolporate, exine semi-tectate, spiculate, regularly areolate, lacking a polar lacunae, spines 3.5-3.9 $\mu \mathrm{m}$ long (type C).

Distribution - The states of Bahia and Minas Gerais in eastern Brazil.

Habitat \& Ecology - The species occurs in 'cerrado' and 'campo rupestre' vegetation. Flowering and fruiting most common from March through May (two records of flowering in September and October).

Note - Some specimens of S. monticola have been misidentified as Vernonia rosmarinifolia Less., a quite different species actually included in the genus Lessingianthus H.Rob. (= L. rosmarinifolius (Less.) H.Rob.). Both species present agglomerate heads
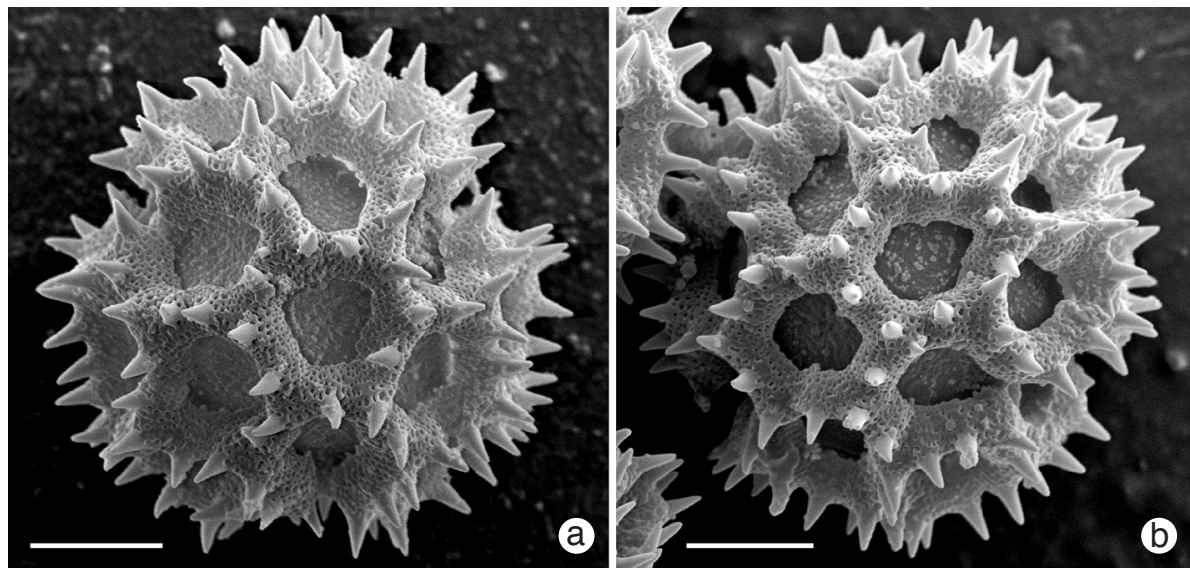

Fig. 1. Pollen grains of Stenocephalum monticola (Mart. ex DC.) Sch.Bip. a. Polar view, showing the colpi converging at the pole; b. subequatorial view. - Scale bar $=10 \mu \mathrm{m}$ (Ganev 3180, HUEFS). 


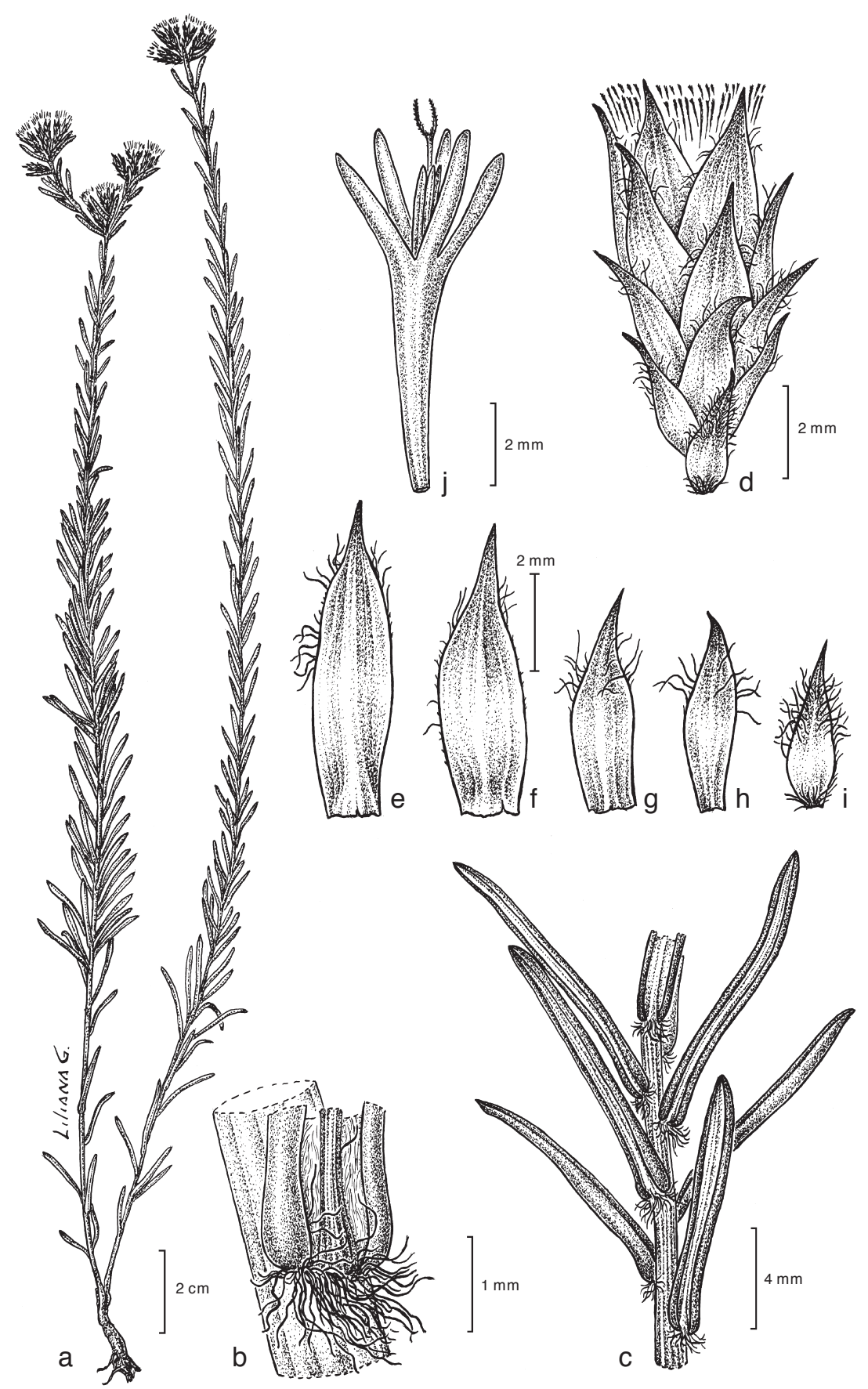

Fig. 1. Stenocephalum monticola (Mart. ex DC.) Sch.Bip. a. Habit; b. leaf blade base; c. portion of the stem; d. involucre; e, f. inner phyllaries; g. middle phyllary; h, i. outer phyllaries; j. corolla showing anthers and style (Ganev 3180, HUEFS). 
at the stem tips, however, they can be distinguished by the involucre shape, florets number and pollen type. Lessingianthus rosmarinifolius has campanulate involucres, 20-25 florets per head and pollen type ' $\mathrm{B}$ ', which is similar to the type ' $\mathrm{C}$ ' but lack the polar lacunae (Pire \& Dematteis 2007). Among the species of the genus Stenocephalum, $S$. monticola seems to be closely related to $S$. apiculatum which has longer leaves and mostly solitary heads arranged in a pseudo-spiciform inflorescence. The presence of agglomerate heads at the stem apex tips is a feature that also occurs in S. tragiaefolium. However, this species can be separated from $S$. monticola by its leaf shape and the number of florets per head, as indicated in the key to the species.

Representative specimens examined:

BRAZIL. Bahia: Mun. Abaíra, Distrito Catoles, encosta da Serra do Atalho em frente ao Mendonça, 3 Apr. 1992, W. Ganev 15 (HUEFS, MBM); Rio de Contas, trilha para Pico Itobira, 26 March 2000, M.D. Moraes \& L.Y.S. Aona 511 (UEC); Mun. Rio de Contas, Pico do Itobira, 12 Apr. 1999, A.M. Amorim, R.C. Forzza, C.B. Costa \& S.C. Sant'Ana 2790 (CEPEC); Mun. Barra da Estiva, estrada Barra da Estiva-Ituaçu, 18 May 1999, V.C. Souza, J.P. Souza, S.I. Elias, W. Forster \& A.C.P. Oliveira

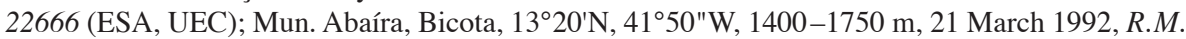
Harley, B. Stannard, T. Silva \& W. Ganev 52764 (CEPEC); Mun. Abaíra, Salão, Campos Gerais do Salão, 2 May 1994, W. Ganev 3192 (HUEFS); Mun. Abaíra, Ägua Limpa, Morro do Cuscuzeiro, 29 May 1994, W. Ganev 3180 (HUEFS); Mun. Rio de Contas, Aeroporto, 17 May 1983, G. Hatschbach 46524 (CEPEC, MBM). Minas Gerais: Mun. Congonhas do Norte, Estrada para Santana do Riacho, Serra da Carapina, 3 March 1998, J.R. Pirani et al. 4160 (SPF); In campo, s.d., H.A. Weddell 1304 (P); Santo Tomé das Letras, 22 March 1987, G. Hatschbach et al. 51220 (C, MBM); Congonhas do Campo, 31 June 1884, A.F.M. Glaziou 14981 (P) (sub V. nettoana Glaz.); Estrada para Ouro Preto, km 44, 13 Sept. 1964, E. Pereira 9222 (RB); Serra dos Cristais, prope Diamantina, 3 Apr. 1892, A.F.M. Glaziou 19491a (P); 46 km S of Conceição do Mato Dentro, 6 Oct. 1980, G.L. Smith et al. 1030 (C); Serra d'Ouro, 1816-1821, A. Saint Hilaire 539 (P).

\section{ACKNOWLEDGEMENTS}

We would especially like to thank the keepers and staff of the herbaria visited for their collaboration. The drawing of the species was prepared by Mirtha Liliana Gómez of the Instituto de Botánica del Nordeste. This work has been supported by grants from the Consejo Nacional de Investigaciones Científicas y Tecnológicas (CONICET), the Secretaría General de Ciencia y Técnica de la Universidad Nacional del Nordeste (SGCyT-UNNE) and the Myndel Botanica Foundation. The second author is a doctoral student of the Facultad de Ciencias Exactas, Físicas y Naturales of the Universidad Nacional de Córdoba, Argentina.

\section{REFERENCES}

Baker, J.G. 1873. Compositae. I. Vernoniaceae. In: C.F.P. Martius, Flora Brasiliensis 6, 2: 1-179. Fleischer \& Co., Leipzig.

De Candolle, A.P. 1836. Prodromus Systematis Naturalis Regni Vegetabilis 5. Treuttel \& Würtz, Paris.

Dematteis, M. 2007. Taxonomic notes on the genus Chrysolaena (Vernonieae, Asteraceae), including a new species endemic to Paraguay. Ann. Bot. Fenn. 44: 56-64.

Erdtman, G. 1966. Pollen morphology and plant taxonomy. Angiosperms. Hafner, New York.

Glaziou, A.F.M. 1905. Liste des plantes du Brésil Central. Bull. Soc. Bot. France 52, Mém. 3: $366-425$.

Holmgren, P.K., N.H. Holmgren \& L.C. Barnett. 1990. Index Herbariorum. I. The herbaria of the World. 8th ed. Regnum Veg. 120. New York Botanical Garden. 
Jones, S.B. 1979. Synopsis and pollen morphology of Vernonia (Compositae: Vernonieae) in the New World. Rhodora 81: 425-447.

Keeley, S.C. \& S.B. Jones. 1979. Distribution of the pollen types in Vernonia (Vernonieae: Asteraceae). Syst. Bot. 4: 195-202.

Pire, S.M. \& M. Dematteis. 2007. Contribución a la flora polínica del nordeste argentino: Tribu Vernonieae (Asteraceae). XXXI Jornadas Argentinas de Botánica. Corrientes, Argentina. Bol. Soc. Argent. Bot. 42 (Supl.): 126.

Punt, W., S. Blackmore, S. Nilsson \& A. Le Thomas. 1994. Glossary of pollen and spore terminology. LPP Foundation, LPP Contributions series No 1. University of Utrecht, The Netherlands.

Robinson, H. 1987. Studies in the Lepidaploa complex (Vernonieae: Asteraceae). I. The genus Stenocephalum. Proc. Biol. Soc. Wash. 100, 3: 578-583.

Schultz-Bipontinus, C.H. 1863. Geschichte der Gattung Lychnophora. Pollichia 20/21: 329-439. 